\title{
Identification of orchardgrass \\ (Dactylis glomerata L.) cultivars by using simple sequence repeat markers
}

\author{
L.-F. Jiang ${ }^{1}$, X.-Q. Zhang ${ }^{1}$, X. Ma ${ }^{1}$, L.-K. Huang ${ }^{1}$, W.-G. Xie ${ }^{2}$, Y.-M. Ma ${ }^{1}$ \\ and Y.-F. Zhao ${ }^{1}$
}

\begin{abstract}
${ }^{1}$ Department of Grassland Science, Animal Science and Technology College, Sichuan Agricultural University, Ya'an, Sichuan, China

${ }^{2}$ The State Key Laboratory of Grassland Agro-ecosystems, College of Pastoral Agriculture Science and Technology, Lanzhou University, Lanzhou, China

Corresponding author: X.-Q. Zhang

E-mail: zhangxq@sicau.edu.cn
\end{abstract}

Genet. Mol. Res. 12 (4): 5111-5123 (2013)

Received April 30, 2013

Accepted September 25, 2013

Published October 29, 2013

DOI http://dx.doi.org/10.4238/2013.October.29.5

\begin{abstract}
The accurate identification of orchardgrass (Dactylis glomerata L.) cultivars is necessary to ensure purity for consumers, the effective utilization of cultivars, and to protect the intellectual property for breeders. Therefore, this study aimed to use SSR to construct DNA fingerprinting of orchardgrass cultivars. The genetic diversity of 32 orchardgrass cultivars originated from 21 countries, but grown in China, was assessed using a set of 29 SSR markers distributed across 9 linkage groups of the orchardgrass genome. A total of 229 bands were detected, with an average of 7.9 bands per marker. The average polymorphic rate for the species was $92.1 \%$. The polymorphism information content ranged from 0.771 to 0.893 .
\end{abstract}


The genetic similarity ranged from 0.55 to 0.84 , which confirmed a high level of genetic diversity among orchardgrass cultivars. The unweighted pair-group method, in combination with the arithmetic mean algorithm (UPGMA) dendrogram and principal coordinate analysis, showed a separation of 6 major clusters among 32 cultivars. The number of distinguishable cultivars ranged from 3 to 23, with an average of 12.1 per primer. Moreover, 11 bands that showed stable and repeatable SSR patterns were amplified by A01E14, $\mathrm{A} 01 \mathrm{~K} 14$, and D02K13. These bands were used to develop the DNA fingerprints for 32 orchardgrass cultivars. In the DNA fingerprints constructed, each cultivar had a unique fingerprinting pattern that was easily distinguished from the others. These results indicate that the SSR marker was polymorphic, and reliable for use in potential large-scale DNA fingerprinting of orchardgrass cultivars.

Key words: Dactylis glomerata L.; Orchardgrass cultivar; DNA fingerprinting; Simple sequence repeats; Discriminatory power

\section{INTRODUCTION}

Dactylis L. is an allogamous, variable monospecific genus that contains several subspecies distinguished by morphology, chromosome number, and distribution. The main species of D. glomerata L. is referred to as orchardgrass or cocksfoot (Lindner and Garcia, 1997; Bushman et al., 2011), and is an economically important and extensively used cool-season perennial forage grass in China, along with many other countries that have temperate and cold climates (Sanada et al., 2010). Because of its high yield, good nutrition, adaptability, and shade tolerance, orchardgrass is widely used for grazing and hay production worldwide (Xie et al., 2012).

Knowledge about genetic diversity and genetic relationships among breeding materials has a great impact on crop improvement (Ganesh and Thangavelu, 1995). Orchardgrass germplasms are diverse, with a high level of genetic diversity, which provides important and valuable breeding materials and gene resources. Plant breeders tend to use clonal breeding, ecotype selection, and morphological mass selection to obtain excellent germplasms for breeding and animal husbandry (Casler et al., 2000). To date, 8 orchardgrass cultivars have been released, and many introduced cultivars have been utilized, in cultivated pastures with high yield and good adaptability to the local environments of China (Xie et al., 2010). With the increased use of orchardgrass cultivars, it is important to select the cultivar with the best fit for a specific service to increase the possibility of suitable performance for users. Therefore, the ability to rapidly and reliably identify a cultivar is becoming increasingly important.

Bushman et al. (2011) assessed the molecular diversity of 3 cultivars and several subspecies of orchardgrass. In addition, another study assessed the isozymes of orchardgrass populations in Europe (Lumaret, 1982). However, a method to identify individual cultivars of orchardgrass has yet to be developed, which would contribute toward maintaining the purity of cultivar utilization for consumers and effective intellectual protection for breeders. 
The genetic diversity of crop species may be determined using morphological and agronomic characteristics, in addition to biochemical and DNA marker analysis (Liu, 1997). Orchardgrass is an allogamous species that has a strong self-incompatibility system (Xie et al., 2012), which guarantees that alleles in each cycle of mating are reshuffled to cause a high degree of genetic variation within populations (Hirata et al., 2011). Therefore, it is difficult to identify orchardgrass cultivars based on physiological and morphological traits, because these traits are subjective and quantitative in practice, limited in number, and affected by environmental conditions and the experience of evaluators (Roldán-Ruiz et al., 2001; Bolaric et al., 2005). To overcome these limitations, a number of molecular markers in orchardgrass have been employed for genetic diversity assessments, genetic mapping, and quantitative trait loci (QTL) analysis, because these traits are not influenced by variable environmental conditions with similar phenotype or plant phenology (Belaj et al., 2002). These markers include sequence-related amplified polymorphism (SRAP) (Zeng et al., 2008; Xie et al., 2011), random amplified polymorphic DNA (RAPD) (Kolliker et al., 1999; Tuna et al., 2004), amplified fragment length polymorphism (AFLP) (Peng et al., 2008), inter-simple sequence repeat (ISSR) (Zeng et al., 2006), and simple sequence repeats (SSR) (Xie et al., 2010; Bushman et al., 2011).

Of these molecular markers, SSR or microsatellites are highly polymorphic, abundant, reliable, and co-dominant. As a result SSR has been widely used for fingerprinting and the identification of various cultivars, including pear (Erfani et al., 2012), apple (Zhang et al., 2012a), and perennial ryegrass (Wang et al., 2009). However, additional genetic information about fingerprinting by SSR for allogamous forage grass species, such as orchardgrass, is still needed. Yet, it is not possible to use small amounts of genotype for identifying pure lines, cloning, or single crosses. Thus, conventional methods have been used for the effective identification of different species to date. Such methods include bulking or pooling strategies using 20-40 individuals to create a pool that represented a cultivar, with the removal of rare alleles from some individuals to form a cultivar (Marshall and Brown, 1975; Morell et al., 1995; Forster et al., 2001).

Recently, several orchardgrass cultivars originating from 21 countries, but which are grown in China, were collected for genotyping their DNA fingerprints. Therefore, the primary goals of this study were to: a) investigate the genetic diversity among these orchardgrass cultivars based on 29 highly polymorphic SSR primer pairs, b) examine the discriminatory power of these SSR markers for orchardgrass cultivars, and c) accurately identify, characterize, and establish DNA fingerprints for orchardgrass cultivars.

\section{MATERIAL AND METHODS}

\section{Plant material}

A total of 32 orchardgrass cultivars or lines were analyzed by SSR markers, of which 27 released cultivars were collected from 21 different countries, and represented most of the commercially available orchardgrass cultivars used in China, in addition to 5 new lines from China (Table 1). The seeds of each cultivar were germinated on absorbent filter paper in Petri dishes at a temperature of $25^{\circ} \mathrm{C}$ after a pretreatment at a temperature of $3^{\circ} \mathrm{C}$. Germinated seeds were transplanted into a sand-peat mixture, and maintained in a 
greenhouse at a temperature $23^{\circ} \mathrm{C}$ and 16 -h photoperiod. Once the seedlings were 9 weeks old, they were transplanted to the field in the experimental station of Sichuan Agricultural University, Ya'an, China $\left(29^{\circ} 58^{\prime} \mathrm{N}, 102^{\circ} 58^{\prime} \mathrm{E}\right)$.

\begin{tabular}{|c|c|c|c|c|}
\hline Code & Name & Country of origin & Abbr. & Improvement status \\
\hline 1 & Krasnodarskaya & Krasnodar territory, Russia & RU & Cultivar \\
\hline 2 & Chinook & Romania & RO & Cultivar \\
\hline 3 & Frode & Sweden & SE & Cultivar \\
\hline 4 & Nika & Poland & PL & Cultivar \\
\hline 5 & Georgikon & Hungary & $\mathrm{HU}$ & Cultivar \\
\hline 6 & Weihenstephaner & Bavaria, Germany & $\mathrm{DE}$ & Cultivar \\
\hline 7 & Asta & Lithuania & LT & Cultivar \\
\hline 8 & Hawk & Iowa, United States & US & Cultivar \\
\hline 9 & Oron & Canada & $\mathrm{CA}$ & Cultivar \\
\hline 10 & Gippsland & Australia & $\mathrm{AU}$ & Cultivar \\
\hline 11 & Akaroa & New Zealand & $\mathrm{NZ}$ & Cultivar \\
\hline 12 & Gulin & Gulin, Sichuan, China & $\mathrm{CN}$ & Cultivar \\
\hline 13 & Baoxing & Baoxing, Sichuan, China & $\mathrm{CN}$ & Cultivar \\
\hline 14 & Chuandong & Daxian, Sichuan, China & $\mathrm{CN}$ & Cultivar \\
\hline 15 & Amba & Denmark & DK & Cultivar \\
\hline 16 & Porto & Italy & IT & Cultivar \\
\hline 17 & Donata & Germany & $\mathrm{DE}$ & Cultivar \\
\hline 18 & Grassland Wana & New Zealand & $\mathrm{NZ}$ & Cultivar \\
\hline 19 & Cambria & Spain & ES & Cultivar \\
\hline 20 & Baridana & Slovakia & SK & Cultivar \\
\hline 21 & Athos & Luxembourg & LU & Cultivar \\
\hline 22 & Aldebaran & Germany & $\mathrm{DE}$ & Cultivar \\
\hline 23 & Endurance & United States & US & Cultivar \\
\hline 24 & Sparta & United Kingdom & UK & Cultivar \\
\hline 25 & Cristobal & France & FR & Cultivar \\
\hline 26 & Intensiv & Czech Republic & $\mathrm{CZ}$ & Cultivar \\
\hline 27 & Baraula & Netherlands & NL & Cultivar \\
\hline 28 & $01-103$ & Sichuan, China & $\mathrm{CN}$ & New line \\
\hline 29 & $02-116$ & Kunming,Yunnan, China & $\mathrm{CN}$ & New line \\
\hline 30 & $79-9$ & Lushan, Jiangxi, China & $\mathrm{CN}$ & New line \\
\hline 31 & 01175 & Dushan, Guizhou, China & $\mathrm{CN}$ & New line \\
\hline 32 & 01472 & Chongqing, China & $\mathrm{CN}$ & New line \\
\hline
\end{tabular}

\section{DNA extraction}

Leaf tissues were collected from young plants, and were frozen by liquid nitrogen for DNA isolation. Approximately $100 \mathrm{mg}$ leaf tissue from 25 genotypes of each cultivar was extracted using the cetyltrimethyl ammonium bromide (CTAB) method (Doyle et al., 1990). DNA quality and concentration were measured by electrophoresis on $0.8 \%(\mathrm{w} / \mathrm{v})$ agarose gel and NanoDrop 1000 ultraviolet and visible spectrophotometry (UV) (ND, NanoDrop Technologies, Inc. Wilmington, DE, USA). The genomic DNA was diluted to $10 \mathrm{ng} / \mu \mathrm{L}$, and stored at $4^{\circ} \mathrm{C}$ until use.

\section{Screening of SSR primer pairs}

Twenty-nine primer pairs were used to evaluate the genetic diversity of the 32 culti- 
vars, which were distributed across 9 linkage groups of the orchardgrass genome (Xie et al., 2010) (Table 2). Primers were screened from 88 SSR primer pairs, using a panel of 4 cultivars, i.e., Frode, Akaroa, Baoxing, and Amba. These primer sequences were kindly provided by Dr. Cai from Japan Grassland Farming and Forage Seed Association, Forage Crop Research Institute, Japan (Hirata et al., 2011).

Table 2. Orchardgrass SSR primers used in this study and the results detected in 32 orchardgrass cultivars.

\begin{tabular}{|c|c|c|c|c|c|c|c|c|c|c|c|}
\hline Primers & LG & $\begin{array}{l}\text { SSR Repeat } \\
\text { motif }\end{array}$ & $\begin{array}{l}\text { Forward primer } \\
\left(5^{\prime}-3^{\prime}\right)\end{array}$ & $\begin{array}{l}\text { Reverse primer } \\
\left(5^{\prime}-3^{\prime}\right)\end{array}$ & $\begin{array}{c}\text { EAS } \\
\text { bp }\end{array}$ & $\begin{array}{l}\text { AT } \\
{ }^{\circ} \mathrm{C}\end{array}$ & $\begin{array}{l}\text { TB } \\
\text { bp }\end{array}$ & $\begin{array}{l}\text { PB } \\
\text { bp }\end{array}$ & $\begin{array}{l}\mathrm{P} \\
(\%)\end{array}$ & PIC & DP \\
\hline $\mathrm{A} 03 \mathrm{C} 05$ & 1 & $(\mathrm{CA})_{11}$ & TAAGAATCGATCCTCCCG & ССТTСТTCCАCТCСGTC & 149 & 52 & 9 & 9 & 100 & 0.868 & 12 \\
\hline A01113 & 1 & & ГGCTGTTTGATCACAGTCA & TTGGACTGCCATTACTAGC & 170 & 52 & 8 & 6 & 75 & 0.868 & 9 \\
\hline A01F24 & 1 & & AAATGTTTTATTCTCAGCCC & GCAAGATGGAATGCTCT & 175 & 52 & 6 & 5 & 83 & 0.827 & 8 \\
\hline $04 \mathrm{H} 05$ & 1 & $(\mathrm{GA})_{15}$ & CAAGAAGGGAGGAAGAAC & [GAGTTGCGTATGCATG & 124 & 52 & 7 & 7 & 100 & 830 & 7 \\
\hline B03E14 & 1 & $(\mathrm{GA})_{33}$ & AGCCTCCAATGTGATAGTT & ТАТTТССТСТTТССАТGATTG & 174 & 52 & 5 & 5 & 100 & 0.778 & 4 \\
\hline B02N20 & 2 & & ATATTGAGGAGACTGTCAGC & AGACACACCAAGTTTGCTA & 159 & 54 & 9 & 9 & 100 & 0.867 & 10 \\
\hline $1 \mathrm{~L} 14$ & 2 & & ACAATGACACCAAATATG & ГCAGCATTGTGACCACC & 173 & 52 & 8 & 8 & 100 & 0.863 & 14 \\
\hline A01L12 & 4 & $(\mathrm{CA})_{10}^{26}$ & ICTCAATCCTTAGACACT & GAGAAATCGTCGTATTGT & 12 & 53 & 7 & 5 & 71 & 0.834 & 8 \\
\hline $\mathrm{A} 02 \mathrm{~A} 10$ & 4 & $(\mathrm{TG})_{16}$ & GGTTACCGATAGTAAGTGGG & GGGGATGGTTGGTTAGTAT & 130 & 54 & 7 & 7 & 100 & 0.850 & 9 \\
\hline A01E02 & 5 & $(\mathrm{TG})_{18}(\mathrm{GA})_{8}$ & TGGAGAAAAAAATGA & ATGCCATTAAGTTCAAAATG & 119 & 52 & 5 & 5 & 100 & 0.771 & 5 \\
\hline A01B10 & 5 & $(\mathrm{CA})_{13}(\mathrm{TC})_{28}$ & TTCCTTGGAAAACATCAA & CTTGCTTACACGGTATCATG & 12 & 52 & 5 & 5 & 100 & 0.799 & 11 \\
\hline B04013 & 5 & $(\mathrm{GA})_{34}$ & rCAGGTACATGGCTTCTCT & CGGCCTATAGATCAAGTCA & 162 & 52 & 6 & 6 & 100 & 0.799 & 8 \\
\hline $\mathrm{B} 06 \mathrm{~N} 03$ & 6 & & & & 125 & 54 & 5 & 5 & 100 & 0.780 & 3 \\
\hline A01K14 & 9 & & ГТС & CTTGG & 164 & 54 & 11 & 10 & 91 & 0.890 & 23 \\
\hline $\mathrm{A} 03 \mathrm{~K} 22$ & 1 & & $\mathrm{AC}$ & & 11 & 55 & 9 & 8 & 89 & 0.876 & 21 \\
\hline $01 \mathrm{E} 09$ & 3 & & GAACA & $\mathrm{AG}$ & 12 & 54 & 8 & 7 & 88 & 0.859 & 15 \\
\hline A03H11 & 3 & & AACACGCAG & ГTTCA & 12 & 52 & 7 & 5 & 71 & 0.857 & 5 \\
\hline B01A02 & 8 & & TTCTCCATTAAGCCTCCAG & GTCCTTGTCGAC & 183 & 55 & 8 & 8 & 100 & 0.868 & 17 \\
\hline A01E14 & - & $\begin{array}{l}(\mathrm{CA})_{17} \\
\mathrm{GCA})_{3}(\mathrm{CA})_{15}\end{array}$ & ACCCGTTTTCTATCTCCAG & GTTCTAGCGTCGTGAGGG & 173 & 55 & 9 & 9 & 100 & 0.861 & 18 \\
\hline A02B24 & - & $(\mathrm{TG})_{30}$ & & & 123 & 53 & 7 & & 86 & 0.811 & 8 \\
\hline $\mathrm{A} 02 \mathrm{~N} 22$ & - & & AACATGTCGTGGTCGTC & TCATTTGTTATGCCGGTAG & 116 & 52 & 9 & 8 & 89 & 0.872 & 19 \\
\hline A03B16 & - & & & & & 53 & 8 & & 88 & 0.873 & 13 \\
\hline A01111 & - & $(\mathrm{CA})_{13}(\mathrm{TC})_{28}$ & CATCGTAATGACTGCTAGTCC & ACAGATCCATCGGTGGTT & 168 & 54 & 9 & 8 & 89 & 0.880 & 13 \\
\hline B01C11 & - & $(\mathrm{GA})_{19}(\mathrm{TG})_{5}$ & GCCATGTAACCAGAATCCTA & TGTTTGTGCATAGATCAAGC & 120 & 52 & 10 & 10 & 100 & 0.893 & 19 \\
\hline & - & & & CCGTGATAACTCATAAACAGC & 127 & 55 & 9 & 9 & 100 & 0.876 & 17 \\
\hline B01F08 & - & & ATTAGTCCGTGTCTCCCAC & TTATCGAGACCTCCAGGAG & 125 & 55 & 8 & 7 & 88 & 0.826 & 7 \\
\hline B05P14 & - & & GTGAGGGCTTGCTTAAG & ATTTGTTGCCATCACCAC & 143 & 51 & 11 & 9 & 82 & 0.885 & 16 \\
\hline B05L12 & - & & TTAGAGGTGAAAATTGATCACA & GTGCTTGGATTATGCTGG & 157 & 51 & 10 & 8 & 80 & 0.879 & 19 \\
\hline D02K13 & - & $(\mathrm{TA})_{s}(\mathrm{TCTA})_{5}$ & TTGTTGTTCCGTTGCAAC & CGCAGGTTTCAATTTAATAGT & 125 & 52 & 9 & 9 & 100 & 0.862 & 14 \\
\hline Total & & & & & & & 229 & 210 & & & \\
\hline Mean & & & & & & & 7.9 & & 92.1 & 0.848 & \\
\hline
\end{tabular}

$\mathrm{LG}=$ linkage groups; EAS = expected amplicon size; $\mathrm{AT}=$ annealing temperature; $\mathrm{TB}=$ total bands; $\mathrm{PB}=$ polymorphic bands; $\mathrm{P}=$ polymorphic rate; $\mathrm{PIC}=$ polymorphism information content; $\mathrm{DP}=$ discriminatory power for number of cultivars.

\section{PCR amplification and electrophoresis}

The SSR-PCR program described by Xie et al. (2012) was followed, with minor revisions to the procedure. Each $15 \mu \mathrm{L}$ PCR contained 50 ng genomic DNA, $0.4 \mu \mathrm{M}$ primer, 1.5 $\mathrm{mM} \mathrm{MgCl}, 240 \mu \mathrm{M}$ dNTP, $0.75 \mathrm{U}$ Taq Gold DNA polymerase, and $1 \mu \mathrm{L}$ distilled water. PCR amplification was conducted on a PTC-200 Thermocycler (Bio-Rad Laboratories, Hercules, CA, USA), with the following program: $94^{\circ} \mathrm{C}$ for $5 \mathrm{~min}, 35$ cycles at $94^{\circ} \mathrm{C}$ for $1 \mathrm{~min}$, varying annealing temperature (Table 2) for $1 \mathrm{~min}$, and $72^{\circ} \mathrm{C}$ for $1 \mathrm{~min}$, followed by a final extension at $72^{\circ} \mathrm{C}$ for $10 \mathrm{~min}$, and then a $4^{\circ} \mathrm{C}$ holding temperature. The PCR amplification products were separated on $6 \%$ denatured polyacrylamide gel electrophoresis (PAGE) using a program of 30 min at $200 \mathrm{~V}$, followed by $2 \mathrm{~h}$ at $400 \mathrm{~V}$. The resulting gel was stained by $\mathrm{AgNO}_{3}$ solution and photographed with a digital camera (D3100, Nikon, Inc. Melville, NY, USA). 


\section{Data analysis}

Unequivocal bands were scored as a data matrix for each locus (1 for present and 0 for absent). Nei and Li's (1979) pairwise similarities between cultivars was computed by using the NTSYS pc2.10 (Rohlf, 2000). A dendrogram was constructed based on the un-weighted pair-group method with arithmetic mean algorithm (UPGMA). The principal coordinate analysis (PCoA) based on the similarity matrix was computed from the same program. The polymorphic rate $(\mathrm{P})$, number of total bands $(\mathrm{TB})$, number of polymorphic bands (PB), and polymorphic information content (PIC) were used to evaluate genetic diversity. PIC was calculated as PIC $=1-\sum \mathrm{P}_{i j}^{2}$, where $P_{i j}$ is the frequency of the $j^{\text {th }}$ allele for the $i^{\text {th }}$ locus, summed across all alleles of the locus (Nei, 1973). The discriminatory power (DP) of each SSR marker was computed by the number of unique sequences required to identify a particular cultivar from the data matrix of all 32 cultivars. The SSR fingerprints of orchardgrass cultivars were constructed following the method reported by Weng et al. (2005). The samples were tested using PGI software (developed by Visual Basic 6.0) (Sun et al., 2005).

\section{RESULTS}

\section{Polymorphism of SSR markers}

The ability of TB, PIC, and discriminatory power (DP) to identify 32 orchardgrass cultivars was calculated (Table 2). PCR products were obtained for all 29 SSR markers from all cultivars. All of the 29 SSRs were polymorphic, and produced a total of 229 bands across the 32 cultivars, of which 210 bands $(92.1 \%)$ were polymorphic. The size of the amplified fragments ranged from $79 \mathrm{bp}$ (D02K13) to $292 \mathrm{bp}$ (A01E14) for all SSR markers. The TB for each marker across different cultivars ranged from 5 (B03E14, A01E02, A01B10, and B06N03) to 11 (A01K14 and B05P14), with an average of 7.9 alleles per marker. The lowest and the highest PIC values were 0.771 and 0.893 for A01E02 and B01C11, respectively, with an average of 0.848 (Table 2).

\section{Genetic relationships based on SSR data}

Dice similarity matrices of orchardgrass genotypes were calculated from SSR data. The pair-wise genetic similarity (GS) coefficients between cultivars ranged from 0.55 (' 01 103 ' and 'Chinook') to 0.84 ('Baoxing' and 'Chuandong'), with an average of 0.67 . The relationship among the 32 cultivars was further determined by UPGMA cluster analysis (Figure 1). Cluster analysis separated 32 cultivars into 6 groups at the GS $=0.69$ level, according to their phylogenetic relationships. The cultivar 'Gippsland' and '01-103' were clustered into Groups I and III, respectively. Group II contained 4 cultivars; namely, 'Donata', 'Cristobal', 'Intensiv', and 'Baraula'. Group IV contained 7 cultivars; namely, 'Gulin', 'Baoxing', 'Chuandong', 'Porto', '79-9', '02-116', and '01175'. Within groups, there was also genetic distance between new lines, such as '02-116', and cultivars, such as 'Baoxing'. All of the cultivars in Group IV were from China. Group V contained 7 cultivars; namely, 'Frode', 'Weihenstephaner', 'Baridana', 'Aldebaran', 'Athos', 'Endurance', and 'Sparta'. 
The rest of the cultivars belonged to Group VI, which was the largest. Similar results were obtained to UPGMA cluster analysis, with the PCoA also separating the 32 cultivars into six groups (Figure 2).

\section{Cultivar identification and DNA fingerprinting}

The number of cultivars distinguished by any SSR marker ranged from 3 (B06N03) to 23 (A01K14), with an average of 12.1 per primer (Table 2). Each amplified band was named depending on the primer that was used and the band size. For example, marker $\mathrm{A} 03 \mathrm{C} 05_{143}$ was a $143 \mathrm{bp}$ band amplified with primer A03C05. Some cultivars could be identified by a single SSR locus from each marker, i.e., A03C05 ${ }_{143}$ for 'Baoxing', A01L14 ${ }_{194}$ for 'Baraula', A01K14 ${ }_{108}$ for 'Intensiv', A02A10 ${ }_{144}$ for '01472', and A03B16 ${ }_{182}$ for 'Cristobal'. Moreover, some SSR loci could discriminate a small number of cultivars, e.g., A03 $05_{132}$ for 'Athos' and 'Aldebaran', B04H05 ${ }_{150}$ for 'Donata', 'Athos', and 'Cristobal', A01K14 ${ }_{121}$ for 'Krasnodarskaya', 'Amba', and 'Grassland Wana', and B01F08 ${ }_{170}$ for 'Hawk', 'Krasnodarskaya', and 'Cambria'. Furthermore, 10 primers had relatively strong discriminatory power, and were able to identify more than 15 cultivars, i.e., A01K14 (23), A03K22 (21), A02N22 (19), B01C11 (19), B05L12 (19), A01E14 (18), B01A02 (17), B01D10 (17), B05P14 (16), and B01E09 (15). In total, marker A01K14 had the largest values for DP (23) and TB (11), which indicated that this primer pair was the most efficient among the SSR markers tested in this study.

Based on the SSR analysis with 29 primers, 11 reproducible and reliable SSR bands were selected, and then used for DNA fingerprinting construction. The 11 selected

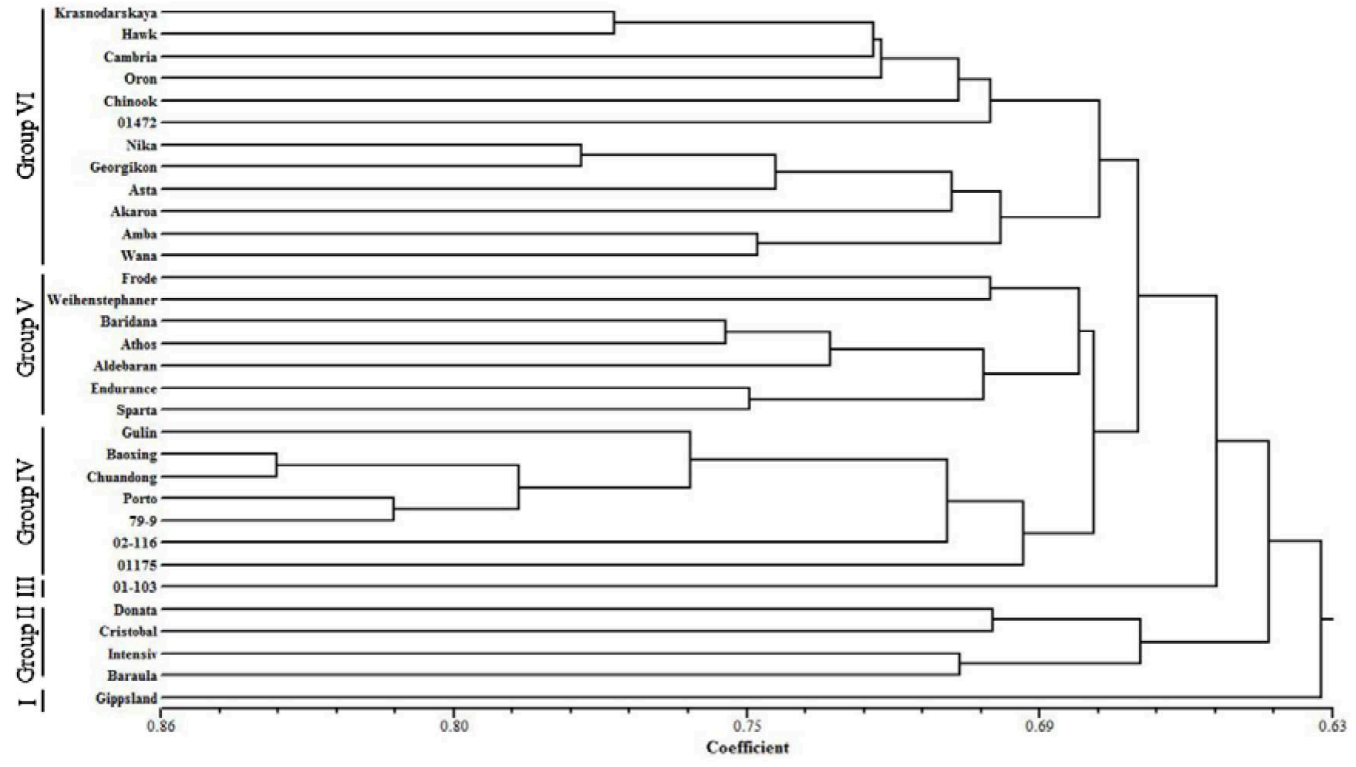

Figure 1. UPGMA dendrogram based on Dice's similarity coefficients among 32 orchardgrass cultivars generated from 29 SSR markers. 
bands derived from the amplification products of A01E14, A01K14, and D02K13, and were numbered from 1 to 11 . Then the DNA fingerprints of the 32 orchardgrass cultivars were generated (Figure 3).

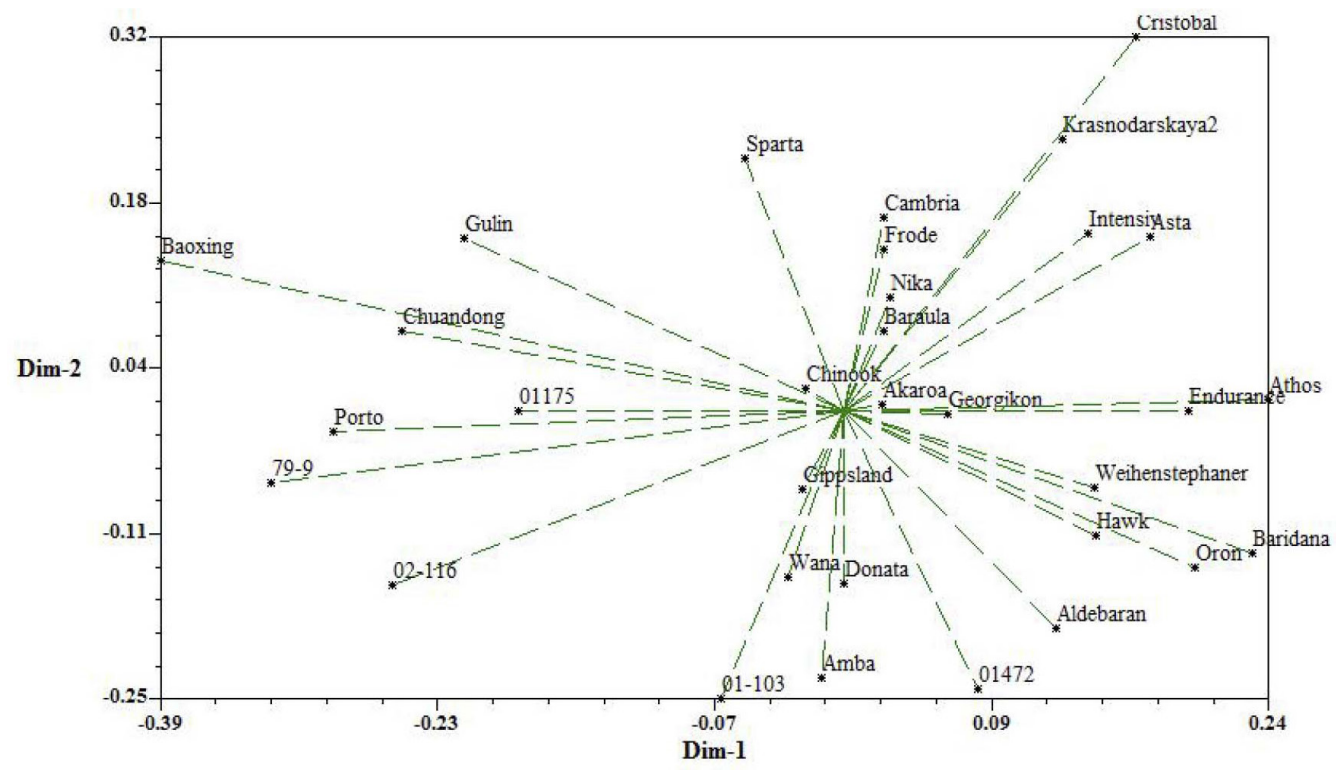

Figure 2. Principal coordinates analysis $(\mathrm{PCoA})$ of 32 orchardgrass cultivars based on the genetic similarity coefficients derived from 29 polymorphic SSR markers.

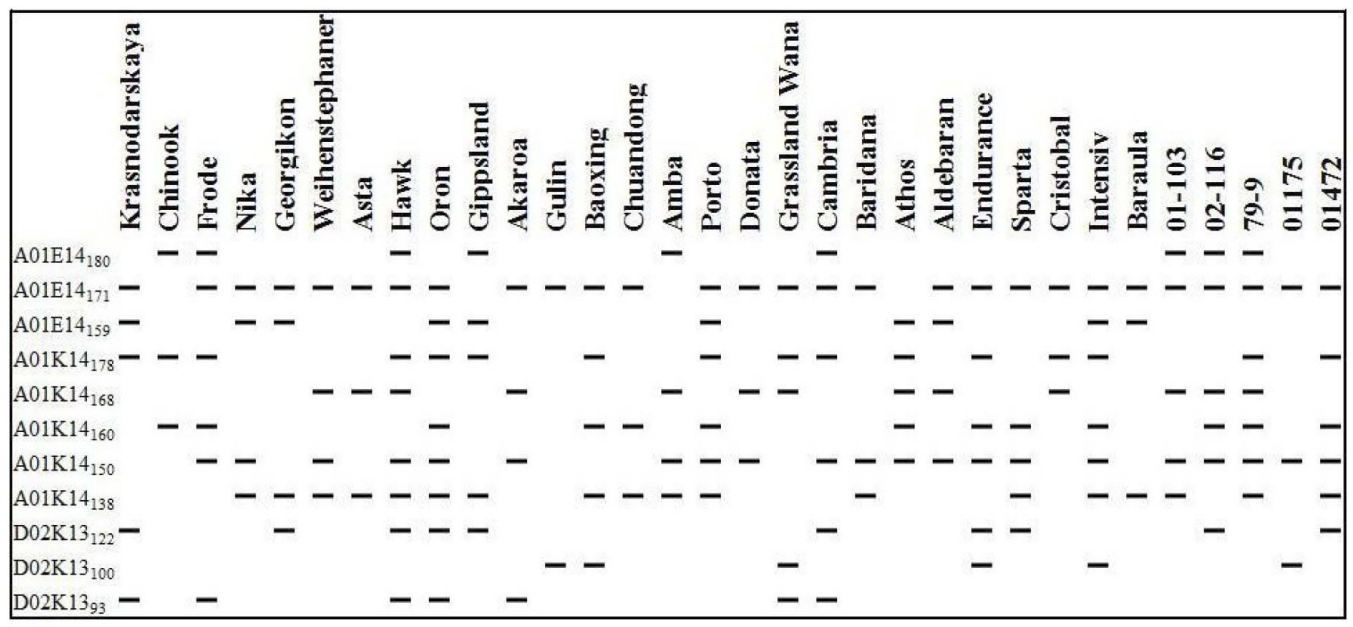

Figure 3. Molecular fingerprint of 32 orchardgrass (Dactylis glomerata L.) cultivars set up by 3 SSR markers. Numbers on the left side of the figure are the numbered 11 bands used for constructing the DNA fingerprints. Marker $\mathrm{A} 01 \mathrm{E} 14_{180}$ was a 180-bp band amplified with primer A01E14. The black rectangles in the figure indicate that there are amplified bands of the orchardgrass cultivars on the site using the primers A01E14, A01K14 and D02K13. 
The DNA fingerprints were converted into computer language expressed with 2 digitals, 1 and 0 . Then the computerized DNA fingerprints were generated (Table 3 ). If the test sample was identical to 1 of the 32 examined cultivars, the computer showed the name of the orchardgrass cultivar. If the test sample was not identical to any of the 32 examined cultivars, the computer identified the sample as a new orchardgrass cultivar, and listed its similarities to each of the known 32 orchardgrass cultivars.

Table 3. Computerized DNA fingerprints of the 32 orchardgrass (Dactylis glomerata L.) cultivars.

\begin{tabular}{lclc}
\hline Orchardgrass cultivars & Computerized DNA fingerprint & Orchardgrass cultivars & Computerized DNA fingerprint \\
\hline Krasnodarskaya & 01110000101 & Donata & 01001010000 \\
Chinook & 10010100000 & Grassland Wana & 01011000011 \\
Frode & 11010110001 & Cambria & 11010010101 \\
Nika & 01100011000 & Baridana & 01000011000 \\
Georgikon & 01100001100 & Athos & 00111110000 \\
Weihenstephaner & 01001011000 & Aldebaran & 01101010000 \\
Asta & 01001001000 & Endurance & 01010110110 \\
Hawk & 11011011101 & Sparta & 01000111100 \\
Oron & 01110111101 & Cristobal & 01011000000 \\
Gippsland & 10110001100 & Intensiv & 01110111010 \\
Akaroa & 01001010001 & Baraula & 01100001000 \\
Gulin & 01000000010 & $01-103$ & 11001011000 \\
Baoxing & 01010101010 & $02-116$ & 11001110100 \\
Chuandong & 01000101000 & $79-9$ & 11011111000 \\
Amba & 10001011000 & 01175 & 01000010010 \\
Porto & 01110111000 & 01472 & 01010111100 \\
\hline
\end{tabular}

\section{DISCUSSION}

\section{Genetic diversity of orchardgrass}

SSR markers have been widely used in genetic diversity analyses (Wang et al., 2009; Bushman et al., 2011; Erfani et al., 2012; Zhang et al., 2012a). In the current study, a total of 29 SSR primer pairs were used to estimate the genetic diversity of a collection of orchardgrass cultivars. The $\mathrm{P}$ value of the 32 orchardgrass cultivars studied was $92.1 \%$, which was higher compared to that reported for expressed sequence tag-simple sequence repeat (EST-SSR) variation $(\mathrm{P}=$ 74.1\%) (Xie et al., 2010), SRAP variation ( $\mathrm{P}=84.38 \%$ ) (Zeng et al., 2008), AFLP variation ( $\mathrm{P}=$ $84.0 \%$ ) (Peng et al., 2008), or ISSR variation ( $\mathrm{P}=86.3 \%)$ (Zeng et al., 2006) in orchardgrass. The average allele of each marker was 7.9, which was higher compared to previous research on 74 accessions (6.3 alleles per locus) of Dactylis species (Xie et al., 2010). Therefore, the results of this study demonstrated the high polymorphism of SSR markers derived from orchardgrass cultivars.

The GS value was higher compared to that previously reported (GS =0.44-0.70) (Bushman et al., 2011), confirming a high level of genetic diversity among orchardgrass cultivars. The UPGMA dendrogram and PCoA showed separation among the 32 cultivars, with most cultivars from the same geographic region being classified into the same group. Moreover, the diversity of cultivars provided an abundance of excellent material of potential use by plant breeders.

\section{Relationship among PIC, TB, and cultivar identification}

PIC and TB are widely used to analyze genetic diversity, because of their discrimina- 
tory power and informative genotyping (Erfani et al., 2012; Hameed et al., 2012), which are related to the effectiveness of SSR markers for the identification of cultivars. Zhang et al. (2012b) selected 17 polymorphic SSR markers to assess differences in 19 mushroom cultivars, with the analyzed cultivars being efficiently differentiated using a combination of 3 polymorphic SSR markers with high PIC. In this report, 29 SSR primer pairs had a mean value of 0.848 (PIC) and 7.9 (TB) among 32 cultivars. The PIC in this study was higher compared to that reported by Xie et al. [2010 (PIC = 0.82), $2012(\mathrm{PIC}=0.81)$ ], confirming that SSR could be effectively used for studying orchardgrass cultivars.

TB could be used to differentiate markers The discernment of markers was associated with TB. For instance, A01K14 produced the highest TB values for 11, with the discriminatory power being high for 23 cultivars. In contrast, the lowest TB was obtained for B03E14 and B06N03, and the lowest number of identified cultivars was 4 and 3. The TB value provided a good reference for the fingerprinting of cultivars, but was not absolute. Higher TB values might identify fewer cultivars, such as B01F08. In contrast, lower TB values might identify more cultivars, such as B04O13. The PIC was not strongly correlated with the number of cultivars identified. For instance, compared with A01E14 (PIC = 0.861), A01I11 expressed a higher PIC value of 0.880 , but identified fewer cultivars. In contrast, a higher TB from B01E09 and A01E14 could identify more cultivars compared to a lower TB from A03H11, based on a higher PIC value. This observation was consistent with the results obtained by Hameed et al. (2012), whereby PIC values serve as a reference for detecting genetic variability, but should be used in combination with other parameters for marker selection. The highest comprehensive scores of the 2 parameters for A01K14 $(\mathrm{PIC}=0.890, \mathrm{~TB}=11)$ could identify the largest number of orchardgrass cultivars. Therefore, a comprehensive understanding of the 2 parameters might contribute toward selecting highly identified efficient markers for orchardgrass fingerprinting.

\section{Sample size selection and fingerprinting construction}

Orchardgrass is a perennial allogamous forage grass species that is mostly cross-pollinated. It is auto-tetraploid, with a large genome (4312 Mbp) (Creber et al., 1994) and selfincompatibility system (Hirata et al., 2011). Compared to other forage material, the breeding of orchardgrass is hampered by its strong self-incompatibility system and severe inbreeding depression, which makes it difficult to produce inbred lines and construct fingerprinting (Xie et al., 2011). A series of molecule studies indicate that the conventional method of bulking could be effectively used for evaluating the diversity of cross-pollinated forage grass species (Marshall and Brown, 1975; Morell et al., 1995; Ghérardi et al., 1998; Forster et al., 2001; Bolaric et al., 2005), which requires a suitable sample size per population (Marshall and Brown, 1975). Moreover, more than 15 plants per population should be used for allogamous species (Morell et al., 1995). Furthermore, for each species and specific marker system, a certain sample size should be tested before conducting a diversity study (Bolaric et al., 2005). For example, a minimum sample size of 40 individuals per populations is required for the characterization of the allogamous tetraploid crop alfalfa (Medicago sativa L.) (Ghérardi et al., 1998), while 20 individuals are required for perennial ryegrass (Lolium perenne L.) cultivars (Bolaric et al., 2005). In this report, a sample size of 25 individuals per population was used for orchardgrass, with an average of $0.848,7.9$, and $92.1 \%$ for PIC, TB, and P, respectively. 
These results were similar to that obtained in a previous study on Dactylis species (Xie et al., 2010), which used 25 individuals per cultivar, and obtained averages of 0.82 (PIC), 8.5 (TB), and $95.2 \%(\mathrm{P})$. These values were higher compared to a previous report by Xie et al. (2012), which used 20 individuals per population, and obtained values of 0.81 (PIC), 7.6 (TB), and $100 \%(\mathrm{P})$. These results support that the optimal sample size required for genetic diversity and fingerprinting of orchardgrass cultivars is about 25 individuals per population, based on SSR markers. However, further studies to confirm the minimum sample size of different molecule markers for orchardgrass are still needed.

The number of distinguishable cultivars ranged from 3 to 23, with an average of 12.1, which was higher compared to that reported by Delgado-Martinez et al. (2012) and Hameed et al. (2012). The use of minimum amounts of DNA bands and primers is an important principle for the construction of DNA fingerprints (Weng et al., 2005). In this report, we successfully constructed the fingerprints of 32 orchardgrass cultivars using 3 SSR markers (A01E14, $\mathrm{A} 01 \mathrm{~K} 14$, and D02K13). We found that each cultivar had a unique fingerprinting pattern, and could be easily distinguished from the other cultivars, indicating that SSR could contribute substantive information to the cultivar identification of orchardgrass. This finding supports the study by Delgado-Martinez et al. (2012), which successfully used 4 SSR markers to construct fingerprints for 77 olive accessions, corresponding to 25 cultivars from the Extremadura region of Spain. These results were also similar to Lee et al. (2012), who used 4 CAPS primers to generate co-dominant polymorphic banding patterns discriminating the Korean ginseng (Panax ginseng C. A. Meyer) cultivars from P. quinquefolius and $P$. notoginseng. In addition, Weng et al. (2005) used 3 out of 120 operon RAPD primers for the fingerprints of 27 Porphyra lines in China. However, the authors converted the specific RAPD molecular markers into SCAR, which indicated its practical application and utility as a good reference for further research. Different identification methods have been report by Tian et al. (2012), who used 9 SSR markers to identify 109 pear accessions, including 92 local Chinese accessions of Pyrus bretschneideri based on clusters directly obtained from the UPGMA dendrogram. Similar results were obtained by Madhou et al. (2013), who used 11 SSR loci to fingerprint and identify cultivars of 88 litchi accessions, based on the UPGMA dendrogram, contributing to the rapid identification of cultivars based on a high distances of the GS coefficient between cultivars. Overall, larger numbers of orchardgrass cultivars could be identified by the amplification of specific fragments from different primers.

\section{Future prospects in orchardgrass fingerprinting}

Cultivar identification is important for the protection and understanding of orchardgrass, which has a fundamental impact on the development of animal husbandry and agricultural practices. This research presented a method for the identification and fingerprinting of orchardgrass. Although, these figures were not absolute, they are expected provide a useful reference for the identification of orchardgrass cultivars. Hence, future research should focus on the collection and preservation of orchardgrass cultivars worldwide, to establish a cultivar fingerprint database for germplasms protection and control, in addition to enhancing the development of animal husbandry and agricultural practices.

In conclusion, the results of the present study showed that SSR-PCR analysis was polymorphic, feasible, and reliable for the identification of orchardgrass cultivars, and that 
each cultivar could be easily distinguished from the others through genetic fingerprinting.

\section{ACKNOWLEDGMENTS}

Research supported by the Earmarked Fund for the Modern Agro-Industry Technology Research System (\#CARS-35-05) and the Ministry of Education of New Funds for Teachers in China (\#20105103110006, \#20115103120004).

\section{REFERENCES}

Belaj A, Satovic Z, Rallo L and Trujillo I (2002). Genetic diversity and relationships in olive (Olea europaea L.) germplasm collections as determined by randomly amplified polymorphic DNA. Theor. Appl. Genet. 105: 638-644.

Bolaric S, Barth S, Melchinger AE and Posselt UK (2005). Genetic diversity in European perennial ryegrass cultivars investigated with RAPD markers. Plant Breed. 124: 161-166.

Bushman BS, Larson SR, Tuna M, West MS, et al. (2011). Orchardgrass (Dactylis glomerata L.) EST and SSR marker development, annotation, and transferability. Theor. Appl. Genet. 123: 119-129.

Casler MD, Fales SL, McElroy AR, Hall MH, et al. (2000). Genetic progress from 40 years of orchardgrass breeding in North America measured under hay management. Crop Sci. 40: 1019-1025.

Creber HMC, Davies MS, Francis D and Walker HD (1994). Variation in DNA C value in natural populations of Dactylis glomerata L. New Phytol. 128: 555-561.

Delgado-Martinez FJ, Amaya I, Sanchez-Sevilla JF and Gomez-Jimenez MC (2012). Microsatellite marker-based identification and genetic relationships of olive cultivars from the Extremadura region of Spain. Genet. Mol. Res. 11: 918-932.

Doyle JJ, Doyle JL and Brown AHD (1990). Analysis of a polyploid complex in glycine with chloroplast and nuclear DNA. Aust. Syst. Bot. 3: 125-136.

Erfani J, Ebadi A, Abdollahi H and Fatahi R (2012). Genetic diversity of some pear cultivars and genotypes using simple sequence repeat (SSR) markers. Plant Mol. Biol. Rep. 30: 1065-1072.

Forster JW, Jones ES, Kolliker R, Drayton MC, et al. (2001). Application of DNA Profiling to an Outbreeding Forage Species. In: Plant Genotyping (Henry RJ, ed.). CAB International, Wallingford, UK, 299-320.

Ganesh SK and Thangavelu S (1995). Genetic divergence in sesame (Sesamum indicum L.). Madras Agric. J. 82: 263-265.

Ghérardi M, Mangin B, Goffinet B, Bonnet D, et al. (1998). A method to measure genetic distance between allogamous populations of alfalfa (Medicago sativa) using RAPD molecular markers. Theor. Appl. Genet. 96: 406-412.

Hameed U, Pan YB, Muhammad K, Afghan S, et al. (2012). Use of simple sequence repeat markers for DNA fingerprinting and diversity analysis of sugarcane (Saccharum spp) cultivars resistant and susceptible to red rot. Genet. Mol. Res. 11: 1195-1204.

Hirata M, Yuyama N and Cai HW (2011). Isolation and characterization of simple sequence repeat markers for the tetraploid forage grass Dactylis glomerata. Plant Breed. 130: 503-506.

Kolliker R, Stadelmann FJ, Reidy B and Nosberger J (1999). Genetic variability of forage grass cultivars: a comparison of Festuca pratensis Huds., Lolium perenne L., and Dactylis glomerata L. Euphytica 106: 261-270.

Lee JW, Bang KH, Kim YC, Seo AY, et al. (2012). CAPS markers using mitochondrial consensus primers for molecular identification of Panax species and Korean ginseng cultivars (Panax ginseng C. A. Meyer). Mol. Biol. Rep. 39: 729736.

Lindner R and Garcia A (1997). Geographic distribution and genetic resources of Dactylis in Galicia (northwest Spain). Genet. Resour. Crop Evol. 44: 499-507.

Liu CJ (1997). Geographical distribution of genetic variation in Stylosanthes scabra revealed by RAPD analysis. Euphytica 98: 21-27.

Lumaret R (1982). Protein variation in diploid and tetraploid orchard grass (Dactylis glomerata L.): Formal genetics and population polymorphism of peroxidases and malate dehydrogenases. Genetica 57: 207-215.

Madhou M, Normand F, Bahorun T and Hormaza JI (2013). Fingerprinting and analysis of genetic diversity of litchi (Litchi chinensis Sonn.) accessions from different germplasm collections using microsatellite markers. Tree Genet. Genomes 9: 387-396.

Marshall DR and Brown AH (1975). Optimum Sampling Strategies in Genetic Conservation. In: Crop Genetic Resources for Today and Tomorrow (Frankel OH and Hawks JG, eds.). Cambridge University Press, Cambridge, 53-80. 
Morell MK, Peakall R, Appels R, Preston LR, et al. (1995). DNA profiling techniques for plant variety identification. Aust. J. Exp. Agric. 35: 807-819.

Nei M (1973). Analysis of gene diversity in subdivided populations. Proc. Natl. Acad. Sci. U. S. A. 70: 3321-3323.

Nei M and Li WH (1979). Mathematical model for studying genetic variation in terms of restriction endonucleases. Proc. Natl. Acad. Sci. U. S. A. 76: 5269-5273.

Peng Y, Zhang XQ, Deng YL and Ma X (2008). Evaluation of genetic diversity in wild orchardgrass (Dactylis glomerata L.) based on AFLP markers. Hereditas 145: 174-181.

Rohlf FJ (2000). NTSYSPC. Numerical Taxonomy and Multivariate Analysis System. Version 2.1. User Guide. Exeter Software, New York, Setauket.

Roldán-Ruiz I, van Eeuwijk FA, Gilliland TJ, Dubreuil P, et al. (2001). A comparative study of molecular and morphological methods of describing relationships between perennial ryegrass (Lolium perenne L.) varieties. Theor. Appl. Genet. 103: 1138-1150.

Sanada Y, Tamura K and Yamada T (2010). Relationship between water-soluble carbohydrates in fall and spring and vigor of spring regrowth in orchardgrass. Crop Sci. 50: 380-390.

Sun JW, Jin DM, Zhou CJ, Yang QK, et al. (2005). Identification of Porphyra lines (Rhodophyta) by AFLP DNA fingerprinting and molecular markers. Plant Mol. Biol. Rep. 23: 251-262.

Tian L, Gao Y, Cao YF, Liu FZ, et al. (2012). Identification of Chinese white pear cultivars using SSR markers. Genet. Resour. Crop Evol. 59: 317-326.

Tuna M, Khadka DK, Shrestha MK, Arumuganathan K, et al. (2004). Characterization of natural orchardgrass (Dactylis glomerata L.) populations of the Thrace Region of Turkey based on ploidy and DNA polymorphisms. Euphytica 135: 39-46.

Wang JP, Dobrowolski MP, Cogan NOI, Forster JW, et al. (2009). Assignment of individual genotypes to specific forage cultivars of perennial ryegrass based on SSR markers. Crop Sci. 49: 49-58.

Weng M, Liu B, Jin DM, Yang QK, et al. (2005). Identification of 27 Porphyra lines (Rhodophyta) by DNA fingerprinting and molecular markers. J. Appl. Phycol. 17: 91-97.

Xie WG, Zhang XQ, Cai HW, Liu W, et al. (2010). Genetic diversity analysis and transferability of cereal EST-SSR markers to orchardgrass (Dactylis glomerata L.). Biochem. Syst. Ecol. 38: 740-749.

Xie W, Zhang X, Cai H, Huang L, et al. (2011). Genetic maps of SSR and SRAP markers in diploid orchardgrass (Dactylis glomerata L.) using the pseudo-testcross strategy. Genome 54: 212-221.

Xie WG, Lu XF, Zhang XQ, Huang LK, et al. (2012). Genetic variation and comparison of orchardgrass (Dactylis glomerata L.) cultivars and wild accessions as revealed by SSR markers. Genet. Mol. Res. 11: 425-433.

Zeng B, Zhang XQ, Lan Y, Yang WY, et al. (2008). Evaluation of genetic diversity and relationships in orchardgrass (Dactylis glomerata L.) germplasm based on SRAP markers. Can. J. Plant Sci. 88: 53-60.

Zeng B, Zhang XQ, Fan Y, Lan Y, et al. (2006). Genetic diversity of Dactylis glomerata germplasm resources detected by inter-simple sequence repeats (ISSRS) molecular markers. Yi Chuan 28: 1093-1100.

Zhang Q, Li J, Zhao YB, Korban SS, et al. (2012a). Evaluation of genetic diversity in chinese wild apple species along with apple cultivars using SSR markers. Plant Mol. Biol. Rep. 30: 539-546.

Zhang RY, Hu DD, Gu JG, Hu QX, et al. (2012b). Development of SSR markers for typing cultivars in the mushroom Auricularia auricula-judae. Mycol. Prog. 11: 587-592. 